Красинский Владислав Вячеславович доктор юридических наук, полковник, член экспертной группы по международному антиэкстремистскому сотрудничеству при МИД России

\title{
О новых особенностях тактики современной террористической деятельности (на примере «Исламского государства»)
}

Источник опубликования: Красинский B.B. О новых особенностях тактики современной террористической деятельности (на примере «Исламского государства») // Военное право. 2017. № 4.

Недавние террористические акты в Ницце, Мюнхене, Лондоне, Барселоне, Камбрильсе, Турку, Сургуте, конспиративно подготовленные и проведенные с применением нетрадиционных средств террора, заставляют говорить о серьезных изменениях в тактике террористов.

Мы видим, что террористическая деятельность не стоит на месте: с каждым годом она усложняется, становится системнее и разнообразнее (для 1990-х - начала 2000-х гг. были характерны единичные акции с использованием террористов-смертников, во второй половине 2000-х гг. стали осуществляться «каскадные» теракты, на современном этапе терроризма используются скоординированные действия небольших боевых групп и комбинированные схемы действий террористов-одиночек). Учитывая динамику обстановки, правоохранительные органы также перестраивают свою работу, меняют формы и методы деятельности, повышают квалификацию руководящего и оперативного состава.

В чем же заключается тактика современной террористической деятельности и какова ее роль?

Тактика террористической деятельности представляет собой образ действий террористических структур (террористов-одиночек) при решении своих задач в конкретных условиях и обстановке.

Правильно выбранная тактика позволяет террористическим структурам 
террористическую деятельность, совершать резонансные теракты, финансово и ресурсно обеспечивать свой оперативный потенциал, поддерживать воспроизводство пособнических сетей, боеготовность и необходимый запас конспирации боевых структурных звеньев. В свою очередь, знание и использование в своих интересах тактических особенностей деятельности международных террористических организаций (далее - MTO) помогает спецслужбам и правоохранительным органам организовывать противодействие противнику:

- выявлять проблемные участки в системе антитеррористической защищенности и на критически важных объектах;

- профилактировать уязвимых в вербовочном плане граждан и сочувствующих террористическим структурам лиц;

- проводить адресные мероприятия по линии информационного противодействия терроризму и экстремизму;

- прогнозировать и предупреждать готовящиеся террористические акции.

В настоящее время на тактику террористической деятельности международных террористических структур оказывают влияние следующие основные факторы:

1. Совершенствование организации и методическое сопровождение лидерами МТО всего террористического процесса. Современная тактика террористов включает анализ и оценку обстановки, планирование террористической деятельности, подбор, подготовку, психологическую обработку и оснащение исполнителей, постановку им задач и заканчивается информационно-пропагандистским сопровождением совершенных террористических актов.

2. Высокая техническая оснащенность и диверсификация источников финансирования и ресурсного обеспечения МТО.

3. Миграция боевиков, обладающих опытом совершения террористических акций. 
4. Развитие межрегиональных и международных связей МТО.

5. Агрессивная пропаганда терроризма и попытки легитимации террористических лидеров и идеологов ${ }^{1}$.

Каждая МТО обладает некоторой спецификой, которая связана с ее управлением, структурным построением, подготовкой боевиков и технических специалистов, ресурсным обеспечением, способами совершения террористических преступлений, применением приемов конспирации и средств маскировки террористической деятельности ${ }^{2}$.

На протяжении последних нескольких лет лидирующие позиции в международном терроризме прочно занимает т.н. «Исламское государство».

Какие же особенности отличают террористический «почерк» одной из наиболее боеспособных, многочисленных и финансово обеспеченных террористических структур - ИГИЛ ${ }^{3}$ ?

Исходя из основных направлений противоправных устремлений МТО «Исламское государство» (далее - МТО «ИГ»), тактику ее деятельности представляется целесообразным анализировать в рамках следующих структурных блоков:

- боевая деятельность;

- террористическая деятельность;

- вербовочная работа и информационно-пропагандистская деятельность.

${ }^{1}$ В настоящее время Соединенными Штатами и их союзниками предпринимаются активные попытки провести подмену понятия «противодействие терроризму» словосочетанием «противодействие насильственному экстремизму». В качестве основного источника террористических угроз предлагается рассматривать «тираническое правление авторитарных режимов», что позволяет оправдывать деятельность незаконных вооруженных формирований (т.н. «умеренной вооруженной оппозиции») и инициировать различные сценарии «цветных революций» для дестабилизации «неугодных» политических режимов.

${ }^{2}$ Подробнее см. Красинский В.В., Машко В.В. Международная террористическая организация «Исламское государство»: история, современность, будущее. М.: Инфра-М, 2017. $108 \mathrm{c}$.

3 Решением Верховного Суда Российской Федерации от 29 декабря 2014 г. № АКПИ14-1424С международная организация «Исламское государство» (другие названия: «Исламское государство Ирака и Сирии», «Исламское государство Ирака и Леванта», «Исламское государство Ирака и Шама») была признана террористической и ее деятельность запрещена на территории Российской Федерации. 


\section{Боевая деятельность}

Активное участие ВКС России в антитеррористической операции в Сирии, а также наступление сил международной коалиции в Ираке привели к радикальным изменениям в тактике боевой деятельности «ИГ»:

1. Боевики стали рассредоточивать свои силы и средства, отказавшись от их концентрации на открытых коммуникациях. Они передислоцировали свои подразделения с открытых участков местности в населенные пункты, рассредоточили тяжелые вооружения и склады с вооружением.

2. Передвижение отрядов и техники стало осуществляться преимущественно в темное время суток, при этом в дневное время боевики предпочитают передвигаться в пустынных районах вне автомобильных дорог. Они отказались от крупных конвоев, стали больше использовать для перемещения мотоциклы и велосипеды.

3. Боевики стали активнее применять меры маскировки, что серьезно затрудняет ведение разведки мест дислокации боевиков. В целях дезинформирования члены «ИГ» целенаправленно выдают за свои позиции дома мирных жителей, вывешивают свои флаги над брошенными строениями и т.п ${ }^{1}$.

4. Несмотря на наличие у боевиков бронетехники они стараются лишь при крайней необходимости использовать тяжелое вооружение, отдавая предпочтение мобильности, благодаря чему «джихадистам» удается максимально быстро и скрытно концентрировать свои силы в местах планируемых нападений.

Отличительными чертами «ИГ» по-прежнему остаются хорошо организованная разведка и гибкость в выборе тактики боя. Сильные концентрированные удары боевики совмещают с множественными небольшими налетами и диверсионно-террористическими актами, изматывающими противника.

${ }^{1}$ Слинкин М. Особенности ведения боевых действий сирийской вооруженной оппозицией // Россия и мусульманский мир. 2016. № 12 (294). С. 66. 
На неконтролируемых или оставленных территориях т.н. «Исламское государство» применяет тактику партизанской войны, пытаясь сковывать силы правительственных войск Ирака и Сирии.

Уникальной особенностью террористической деятельности современных МТО является стремление руководящего звена террористических структур комплексно использовать имеющиеся у террористов силы и средства в их оптимальном сочетании путем проведения дополняющих друг друга взаимосвязанных террористических акций.

\section{Террористическая деятельность}

Рассматривая террористическую деятельность ИГИЛ, следует отметить, что арсенал методов, применяемых «ИГ» для совершения террористических актов, неограничен, однако в большинстве случаев ею используются террористы-смертники (как правило, водители транспортных средств, начиненных взрывчаткой).

С целью запугивания и деморализации своих противников «ИГ» регулярно проводит террористические акции, а также массовые казни захваченных в плен солдат, заложников и мирных жителей.

Новой тенденцией стало привлечение к совершению террористических актов, а также к казням заложников детей (в возрасте от 12 лет). При этом они участвуют в казнях и как исполнители, и как зрители.

Получает распространение концепция «автономного» (индивидуального) «джихада», которая не требует традиционных средств террора (Ницца, Мюнхен, Лондон, Барселона, Турку и др.)).

Наряду с боевиками-одиночками основной акцент в новой тактике террористической деятельности ИГИЛ делается на массовом формировании «спящих» террористических ячеек, укомлектованных подготовленными террористами, имеющими опыт ведения боевых действий и совершения преступлений в зонах вооруженных конфликтов.

В ходе обучения в лагерях подготовки боевиков (т.н. «муаскары») рекрутам ставятся конкретные задачи по непосредственному участию в 
подготовке и совершении терактов после возвращения в регионы исхода. В этих целях их активно обучают минно-взрывному делу, отрабатывают каналы конспиративной связи. При этом осведомленность данных лиц о проведении в отношении них оперативно-разыскных мероприятий и следственных действий приводит к тому, что их возвращение на родину осуществляется с соблюдением особых мер конспирации.

Важной составляющей тактики MTO «ИГ» является активная вербовочная работа и информационно-пропагандистская деятельность.

Вербовочная деятельность лежит в основе поддержания высокого оперативного потенциала, высокой численности структурных звеньев и пособнических сетей «Исламского государства»1.

Вербовочная деятельность МТО сопровождается популяризацией экстремистской идеологии и совершения преступлений террористической направленности ${ }^{2}$.

Она связана с пропагандой религиозного радикализма, героизацией образа его сторонников, идеализацией «справедливых» общественных отношений, к установлению которых стремятся террористы, обещаниями материальных благ ${ }^{3}$.

Активная агитация за выезд в «халифат» проводится лицами, уже принимающими участие в деятельности МТО «ИГ». Основным объектом внимания вербовщиков выступает молодежь.

При вовлечении в террористическую структуру вербовщики используют психологические особенности вербуемых лиц, обусловленные их несформировавшимся мировоззрением, поверхностным знанием религиозных канонов, а также недовольством действующей властью. Во время общения

1 Красинский В.В. Противодействие использованию террористическими организациями каналов миграции и вовлечению граждан России в террористическую деятельность за рубежом // Современное право. 2017. № 2. С. 88-93.

${ }^{2}$ Комиссаров B., Агапов A. Ответственность за прохождение обучения в целях осуществления террористической деятельности // Уголовное право. 2016. № 5. С. 37.

${ }^{3}$ Капинус O.C. Научные подходы к противодействию вербовочной деятельности международных террористических организаций // Противодействие терроризму. Проблемы XXI века. 2016. № 1. С. 5. 
основной акцент вербовщиками делается на героизации воинов «джихада», превознесении их военных успехов, необходимости восстановления справедливости и защите «истинных» последователей ислама от притеснения ${ }^{1}$.

В связи с ощутимыми потерями МТО после подключения России к операции по борьбе с террористами в Сирии и наступлением коалиционных сил на позиции «Исламского государства» в Ираке террористы осуществляют поиск запасных плацдармов для переноса своей террористической активности. Характерная для периода 2012-2015 гг. массовая агитация за выезд в «халифат» сменилась призывом активизировать террористическую деятельность «на местах».

В зависимости от регионов и стран мира вербовочная деятельность «ИГ» имеет свою специфику. В частности, в странах Юго-Восточной Азии пропаганда МТО «ИГ» во многом ориентирована на вербовку молодых одиноких студентов, малолетних правонарушителей и молодежи из семей, связанных с деятельностью радикальных религиозных организаций. Присоединение к МТО «ИГ» дает данным категориям граждан ощущение причастности к «большому благородному делу».

Вербовщиками МТО «ИГ», как правило, являются молодые люди в возрасте до 35 лет, обладающие высокой коммуникативностью, способностью к убеждению, внешне строго соблюдающие нормы ислама.

В настоящее время МТО «ИГ» использует как активные способы вовлечения граждан в свою деятельность, при котором ее эмиссары сами определяют потенциальных кандидатов, осуществляют их проверку и последующую психологическую обработку (адресное воздействие), так и способы пассивного вовлечения, когда сочувствующие террористам граждане пытаются установить контакты с МТО «ИГ» по собственной инициативе в результате ее масштабной информационно-пропагандистской деятельности.

\footnotetext{
${ }^{1}$ Махди А. Исповедь вербовщика ИГИЛ. М.: Издательские решения, 2016. 33 с.
} 
Глобальная сеть рассматривается лидерами МТО «ИГ» в качестве одного из основных каналов распространения информации управляющего воздействия, пропаганды идей «джихада».

Яркий, регулярно обновляемый контент сторонников МТО «ИГ» в сети Интернет является основным мотивирующим фактором проявления интереса к деятельности террористической организации со стороны радикально настроенных мусульман. Часть из них стремится инициативно выйти на связь с эмиссарами МТО или самостоятельно выезжает в Сирию, где вступает в ряды террористических организаций.

Использование современных средств телекоммуникации позволяет вербовщикам и кураторам ИГИЛ подбирать и изучать новых участников, дистанционно управлять действиями завербованных, формировать «спящие» ячейки по Интернету.

«Исламское государство» отличается высоким уровнем применения передовых информационно-коммуникационных технологий.

Организация имеет собственные медийные центры, занимающиеся созданием и распространением пропагандистского контента. К их числу относятся: медиа-агентство «Аль-Фуркан» (Al-Furqan Institute for Media Production), медиа-агентство «Итисаам» (I’tisaam Media Foundation), медиацентр «Аль-Хайят» (Alhayat Media Cente) и медиа-фонд «Айнад» (Ajnad Media Foundation).

Информационно-пропагандистской деятельностью МТО «ИГ» на русском языке руководит Ислам Атабиев (Абу Джихад). В июне 2015 г. он основал медиа-агентство «Furat Media», объединяющее все русскоязычные ресурсы организации в сети Интернет и занимающееся производством видеопродукции на русском языке.

Информационно-пропагандистская деятельность МТО «ИГ» ориентирована на разные целевые аудитории, одной из которых являются осужденные - «братья, страдающие в тагутском плену».

К числу современных тенденций в криминогенной среде, обусловленных агрессивной информационно-пропагандистской 
деятельностью т.н. «Исламского государства», относятся активизация религиозно-экстремистской пропаганды международных террористических организаций в исправительных учреждениях и связанный с ней рост количества осужденных, одобряющих их деятельность.

В местах лишения свободы формируются законспирированные ячейки «тюремные джамааты», осуществляющие активную религиозноэкстремистскую обработку осужденных и воздействие на администрацию исправительных учреждений для укрепления своего статуса в тюремной и

е Пропагандисты из числа членов радикальных религиозных структур рризывают к формированию вооруженных групп во главе с амиром, к жмуджахедству», «шахидству», к пожертвованию своей жизнью на пути рслама, к полному подчинению человека воле Аллаха, выполнению любых его хприказов», формируя установки на совершение насильственных действий, в пом числе террористического характера.

и Основными модераторами религиозно-экстремистских идей являются осужденные, проходившие диверсионную и военную подготовку в лагерях боевиков на Ближнем Востоке, а также лица, принимавшие участие в боевых действиях на стороне МТО «ИГ» в зоне вооруженных конфликтов в Сирии и Ыраке.

б Как правило, пропагандистские мероприятия осуществляются в «мягкой форме». К примеру, при ежедневном просмотре заключенными новостных вередач идеологами радикального ислама выражается активная поддержка действий лидеров и функционеров МТО «ИГ». ИГИЛ представляется как өбразец структуры, действующей в интересах всех «истинных» мусульман. Еоследующая идеологическая обработка поддающихся на пропаганду нсужденных проводится в ходе индивидуальных бесед.

и Перспективные направления противодействия новым элементам жактики МТО «ИГ» связаны с моделированием террористической 
деятельности, регулярным анализом ее признаков и тактических особенностей.

В основе адекватного реагирования правоохранительных органов на изменения в тактике преступной деятельности МТО лежит построение, своевременная корректировка основных террористических моделей и организация контртеррористических мероприятий с их учетом.

Можно выделить несколько типовых моделей террористической деятельности:

- модель руководителя террористической структуры (лидера бандгруппы, ячейки);

- модель активного члена террористической организации;

- модель вербовщика МТО;

- модель террориста-смертника (индивидуального джихадиста);

- модель участника транзитного канала переправки в зону террористической активности;

- модель связника (курьера) МТО;

- модель пособника террористов.

Каждая модель базируется на поведенческих признаках и материальных следах подготовки и совершения составов преступлений, характерных для той или иной категории участников террористической деятельности. Применение моделирования в ходе планирования, организации и контроля оперативнорозыскной деятельности способствует упорядочению комплекса оперативнорозыскных и технических мероприятий и учету важнейших угрозообразующих факторов и террористических устремлений.

Анализ террористической деятельности может включать как признаки террористической деятельности конкретной МТО, так и характерные для ее проведения ситуации (предстоящие важные общественно-политические мероприятия, визиты государственных деятелей, обострения обстановки и др.). 
Важное значение имеют комплексная оценка и сравнение тактики противоправной деятельности МТО в различные периоды (определенные тактические элементы могут «уходить» из арсенала террористической деятельности, модернизироваться или вновь использоваться), у различных террористических структур (у конкурентов, союзников или иных аффилированных структур может присутствовать многообразие форм реализации одних и тех же тактических приемов), в различных регионах.

Проведенный анализ современной террористической деятельности т.н. «Исламского государства» показал, что тактика МТО не является изолированным и статичным явлением, она зависит от ряда факторов. Современные изменения в тактике террористов ИГИЛ (сочетание групповой организации террористической деятельности и индивидуального «джихада», рост числа и расширение географии деятельности «спящих» ячеек и др.) нуждаются в своевременном гибком реагировании со стороны спецслужб и правоохранительных органов. Учет тактических особенностей деятельности террористических структур, моделирование, анализ и сравнение элементов тактики противоправной деятельности МТО способствуют оптимизации расстановки и использования сил и средств спецслужб и правоохранительных органов, концентрации усилий на приоритетных направлениях розыска, разработки, привлечения к уголовной ответственности лидеров, активных членов и пособников террористов. 